\title{
Pengaruh Hipnoterapi pada Santriwati yang Menderita Psikosomatis di MA Muallimat NW Pancor
}

\author{
Mustafid Amna Umary ${ }^{1 *}$ \\ 1. Fakultas Psikologi, Universitas Surabaya, Surabaya \\ *E-mail: erlanggakusumaperdanasaputra@gmail.com
}

\begin{abstract}
Abstrak
Hipnosis merupakan salah satu bentuk terapi yang dipergunakan dalam psikoterapi, dengan memanfaatkan status kesadaran hipnotik pasien untuk melakukan perubahan terhadap diri mereka melalui sugesti untuk memunculkan kondisi relaks, fokus, atau konsentrasi. Hipnoterapi bertujuan untuk memunculkan kondisi relaks dalam tubuh yang mampu memulihkan kondisi pasien dari beban psikologis yang dialaminya serta mempercepat peroses kesembuhan pada fisiologis dan psikologis akibat distress psikologis yang menjadi faktor utamanya. Psikosomatik merupakan keluhan-keluhan yang muncul pada fisiologis karena faktor stress psikologis yang menjadi pemicu utama dengan menampilkan keluhan-keluhan klinis. Pada penderita psikosomatis, penyebab terganggunya fisiologis umumnya dihubungkan dengan gangguan psikofisiologis sebagai pencetus utamanya yang mengakibatkan penderita mengeluhkan beragam gangguan pada fisiknya. Clinical hypnosis atau hypnotherapy merupakan jenis hipnosis yang dipergunakan dalam bidang penyembuhan fisik dan psikis, salah satu diantaranya sebagai media penyembuhan masalah psikosomatis. Misalnya stress, depresi, kecemasan, dan lain sebagainya. Tujuan penelitian ini adalah untuk memahami pengaruh pemberian hipnoterapi terhadap perubahan psikologis dan perubahan simptom-simptom klinis pada penderita psikosomatis. Metodologi dalam penelitian ini menggunakan metode desain satu kasus. Tingkat somatisasi klien diukur dengan menggunakan instrumen SCL-90-R dan wawancara terstruktur sebelum dan sesudah perlakuan. Penelitian ini dilakukan pada santriwati MA Muallimat NW Pancor Tahun 2017 yang seringkali di rujuk ke ruang Unit Kesehatan Sekolah. Hasil penelitian ini menunjukkan efektifitas hipnoterapi dalam mengobati keluhan pencernaan dan asma serta menurunkan tingkat rasa sakit yang dialami oleh santriwati MA Muallimat dengan gangguan psikosomatis.
\end{abstract}

\section{Keywords: Hipnoterapi; Psikoterapi; Psikosomatis; SCL-90-R; MA Muallimat NW Pancor.}

\section{Mukadimah}

Masalah psikologis merupakan masalah yang umum ditemukan dalam pelayanan medis profesional yang berdampak terhadap kondisi medis umum (Schmitz, et al, 2002). Masalah psikologis yang memunculkan simptom klinis tanpa adanya gangguan organis yang khas merupakan gambaran umum dari keluhan psikosomatis (Ardani, 2008). Kondisi ini muncul akibat ketidak mampuan mental dalam mengatasi stressor yang dihadapinya, dan berdampak pada munculnya keluhan fisik. Distress psikologis merupakan faktor utama munculnya psikosomatis dengan keluhan fisik tanpa adanya penyakit organis yang khas sebagai diagnosis utama. Psikosomatik merupakan keluhan-keluhan yang muncul pada fisiologis karena faktor stress psikologis yang menjadi pemicu utama dengan kesan menampilkan keluhan-keluhan klinis.

Pada penderita psikosomatis, penyebab terganggunya fisiologis umumnya dihubungkan dengan gangguan psikofisiologis sebagai pencetus utamanya yang mengakibatkan penderita mengeluhkan beragam gangguan pada fisiknya. Ketidak mampuan mengatasi problem psikologis seperti stress, kecemasan, dan depresi akan mengakibatkan tubuh rentan mengalami serangan penyakit organis seperti gastrointestinal, asmatikus, sakit kepala, dan beragam gangguan fisik lainnya. 
Banyak keluhan penyakit berawal dari masalah gangguan pikiran yang berat (Gunawan, 2007., Hakim 2010, Putranto, 2016., Junaidi 2012., Guze, 1997., dan Ardani, 2008). Diantaranya berdampak langsung terhadap gejala fisik seperti psikosomatis. Psikosomatis merupakan suatu gangguan fisik yang disebabkan oleh kondisi kejiwaan seseorang yang secara langsung menimbulkan keluhan-keluhan fisik (Junaidi, 2012). Dalam DSM - IV merupakan faktor-faktor psikologis yang mempengaruhi kondisi medis (DSM - IV dalam Williams \& Wilkins, 2004).

Psikosomatis pertama kali diperkenalkan oleh Johann Christian Heinroth pada tahun 1818 yang kemudian dipopulerkan oleh psikiater Jerman, Maximilian Jacobi (Ardani, 2008). Psikosomatis adalah gabungan dua kata "Psyche" dan "Soma" yang menekankan hubungan kausalitas diantara keduanya. Dalam pandangan ini, semua penyakit dan atau keluhan suatu penyakit tertentu dibangun oleh keluhan yang didasari oleh faktor psikologis.

Hipnosis didefinsikan sebagai sebuah alat yang dipergunakan dalam psikoterapi, namun bukan psikoterapi yang berdiri sendiri, dengan memanfaatkan status kesadaran hipnotik pasien untuk melakukan perubahan terhadap diri mereka (Putranto, 2016). Dalam hypno-healing, hipnosis didefinisikan sebagai teknik atau praktik mempengaruhi orang lain secara sengaja untuk masuk kedalam kondisi yang menyerupai tidur, dimana seseorang yang terhipnosis bisa menjawab pertanyaan yang diajukan, serta menerima sugesti tanpa perlawanan (Budi, 2010). Mosby medical Encyclopedia edisi 1992 mendefinisikan hipnosis sebagai keadaan pasif dan trans yang mirip dengan tidur normal ketika persepsi dan ingatan diubah, sehingga meningkatkan ketanggapan terhadap sugesti (dalam seni hipnosis Hunter, 2011).

Hipnosis tidak berarti tidur atau bentuk dari kehilangan kesadaran dan atau kendali terhadap diri sendiri. Seseorang yang berada dalam kondisi hipnosis justru dalam keadaan terjaga tentang kontrol dirinya secara baik. Bahkan dalam kondisi hipnosis, seseorang pada dasarnya berada pada level kesadaran tertinggi terhadap dirinya sendiri (Putranto, 2016). Dalam The Handbook psychiatry memberikan definisi bahwa Hipnosis adalah induksi dari keadaan konsentrasi fokal dengan pengecilan dari kesadaran perifer, lazimnya, tetapi tidak secara eksklusif, ditimbulkan melalui penggunaan sugesti (Guze, 1997). Hipnosis dapat diartikan sebagai sebuah kondisi relaks, fokus, atau konsentrasi (Wong, 2009).

Hipnosis digunakan dalam peroses penyembuhan psikis dalam psikoterapi, namun bukan psikoterapi yang berdiri sendiri, dengan memanfaatkan status kesadaran hipnotik pasien untuk melakukan perubahan terhadap diri mereka (Putranto, 2016). Hipnosis bertujuan untuk memunculkan kondisi relaks dalam tubuh seseorang yang bertujuan untuk memulihkan kondisi sesorang akan pulih dari beban psikologis yang dialaminya (Guze, 1997). Salah satu media dalam peroses penyembuhan gangguan psikologis adalah hipnotis (Ardani, 2008).

Kondisi hipnotik dapat berlangsung disebabkan adanya gap duration dalam berlangsungnya perjalanan impuls yang diterima, dan perjalanan respon sebagai reaksi terhadap suat impuls, serta terjadinya atau munculnya reaksi, yang diakibatkan adanya kelambatan berlangsungnya proses tersebut (Prabowo, 2009) disaat seperti itulah terjadinya perubahan gelombang otak menuju relaksasi dalam atau yang disebut dengan kondisi hipnosis melalui penggunaan sugesti sebagai jembatan untuk mengakses kondisi rileks, dalam kondisi rileks inilah, sugesti positif akan dapat secara mudah diterima otak untuk mengubah kebiasaan lama dengan program baru yang disugestikan hipnoterapis.

Menurut Adi W. Gunawan, ada lima karakteristik utama dalam kondisi hipnosis atau trance (Gunawan, 2007), yaitu: Relaksasi fisik yang dalam, Perhatian yang sangat terpusat, Peningkatan kemampuan indera, Pengendalian refleks dan aktivitas fisik, dan Respon terhadap pengaruh pascahipnosis. Sugesti yang diberikan saat dalam hipnosis dapat langsung diterima dengan mudah, menolak ataupun bangun secara spontan dari relaksasi hipnosis. Selama kondisi sugesti tidak bertentangan dengan nilai dasar yang dipegang subjek maka sugesti akan dijalankan ketika ia telah bangun dari kondisi trance. Catatan untuk sugesti positif akan lebih mudah diterima oleh subjek daripada sugesti negatif. 
Jadi, ketika seseorang berada dalam kondisi hipnosis atau trance dengan pikirannya yang diarahkan menuju pikiran bawah sadar, subjek mengalami kondisi yang sangat relaks dengan daya konsentrasi yang cukup tinggi sehingga ia cenderung mudah untuk disugesti, khususnya sugesti positif karena ketika pascahipnosis, pemberian sugesti positif cenderung dapat diterima daripada sugesti negatif. Selain itu, melalui sugesti, seorang subjek yang berada dalam bawah sadarnya justru memiliki kemampuan mengingat yang luar biasa dari keadaan normal. Dalam kondisi hipnosis, sugesti positif akan mampu mengubah kebiasan negatif (Putranto, 2016), menyembuhkan psikosomatis (Holdevici \& Craciun, 2012., Gunawan, 2007., dan Hakim, 2010) menyembuhkan post traumatic syndrome disorder (Enea dan Dafiniou 2012), dyspepsia atau gangguan gastrointestinal (Calvert, et al, 2002), migrain (Emmerson \& Trexler, 1999), dan menyembuhkan gangguan kecemasan (Abdeshahi., et al., 2015).

Clinical hypnosis atau yang dikenal dengan hipnoterapi merupakan media terapi untuk mengatasi persoalan fisik maupun psikologis dengan menggunakan pendekatan sugesti.Dengan demikian, peneliti tertarik untuk mengkaji hipnosis sebagai media traupetik pada peroses penyembuhan gangguan psikosomatis.

\section{Metode}

Metode dalam penelitian ini menggunakan desain satu kasus yang menitik beratkan pada pengkuran individu menggunakan wawancara terstruktur dan SCL - $90 \mathrm{R}$ saat sebelum diberikan intervensi dan setelah diberikan intervensi dalam desain penelitian eksperimental dengan satu subjek (Halgin \& Whitbourne, 2010), eksperimental subjek tunggal berfokus pada pemeriksaan terhadap perubahan perilaku pada seorang individu (Shaugnessy, 2012).

Subjek penelitian ini adalah santriwati MA Muallimat NW Pancor yang sedang duduk di kelas $\mathrm{X}$. Instrumen yang digunakan dalam penelitian ini adalah SCL-90-R yang merupakan daftar symptom klinis yang mengukur beberapa kondisi klinis. SCL90-R dapat digunakan untuk mengevaluasi efektifitas terapi tertentu dalam mereduksi symptom klinis sebelum dan sesudah intervensi (Halgin \& Whitbourne, 2010). Alat ukur SCL-90-R yang dikenal instrumen multidimensi yang merangkum 9 kondisi klinis, salah satu diantaranya memberikan gambaran psikosomatis yang dialami pasien pada pelayanan medis professional (Schmitz, et al, 2002) dan memberikan gambaran bagi klinisi dan peneliti dengan pengukuran kuantitatif (Derogatis dalam Halgin \& Whitbourne, 2010).

Subjek dalam penelitian ini merupakan santriwati yang telah melakukan pemeriksaan dokter di sekolah dan dinyatakan tidak memiliki keluhan suatu penyakit tertentu secara spesifik pada diagnosis yang khas. Dalam laporan rekam medis dokter yang memeriksa memberikan catatan riwayat sakit yang dialami subjek, diantaranya: asma bronchial, gangguang pencernaan; dyspepsia, migrain, dan disminorhea. Subjek telah mendapatkan asesemen psikologis SCL-90-R setelah direveral oleh petugas UKS ke ruang BK karena dilaporkan bahwa subjek yang bersangkutan sering mendapatkan perawatan di Ruang UKS.

Kriteria kelayakan yang digunakan dalam studi yang dilakukan adalah laporan petugas UKS, laporan rekam medik dokter sekolah, dan hasil pemeriksaan menggunakan asesemen SCL-90-R. Selama wawancara diperoleh informasi yang disajikan kondisi subjek dengan keluhan psikologis yang menjadi tolak ukur sebagai criteria subjek penelitian dengan gangguan psikosomatis. Persetujuan subjek diperoleh sebelum prosedur terapi dan penelitian telah dijelaskan sepenuhnya. Subjek memberikan laporan perkembangannya melalui wawancara dan asesemen SCL-90-R saat sebelum, dan setelah tahap intervensi akhir diberikan dengan menerapkan program terapi menggunakan teknik hipnoterapi.

\section{Hasil}

Karakteristik subjek diketahui bahwa subjek merupakan anak pertama dari dua bersaudara dengan jarak kelahiran yang relatif jauh dari adik kandung subjek. Subjek cenderung dimanjakan oleh kedua orang tuanya yang berdampak terhadap kemampuan subjek dalam membentuk kemandirian diri dan cenderung bergantung kepada orang tua dan mencari perhatian lebih sebagai anak yang ingin mendapatkan dominansi kasih sayang dari orang 
tua.. Subjek seringkali mengeluhkan ketidak nyamanan pada oragan tubuh terutama organ gastrointestinal dan sesak nafas jika adanya tekanan psikologis yang dialaminya, terutama sekali masalah yang berkaitan dengan masalah keluarga dan penerimaan terhadap lingkungan baru.

Subjek seringkali dibawa ke ruang UKS oleh petugas jaga karena laporan keluhan nyeri ulu hati dan beberapa diantaranya dibawa dalam kondisi tidak sadarkan diri setelah merasakan nyeri dada akibat sesak nafas yang dideritanya. Frekuensi perawatan yang didapatkan oleh subjek 3-5 kali dalam satu minggu. Dari keterangan subjek, didapatkan bahwa keluhan yang dialami seringkali muncul jika ada pressor psikologis yang bagi subjek menimbulkan keluhan fisik walaupun sudah berulangkali di rujuk kedokter untuk di periksakan kondisi fisiknya, namun tidak ditemukan gangguan fisik yang khas.

Hasil pemeriksaan SCL-90-R pada fase awal/ base line, diperoleh angka $87 \%$ pada simptom psikosomatis. Kondisi ini diperkuat oleh laporan subjek terkait keluhan-keluhan fisik yang dialaminya seperti gangguan pencernaan, merasa sulit bernafas, sakit kepala, dan disminorhea saat menstruasi. Sebelum mendapatkan intervensi traupetik dengan pendekatan hipnoterapi, subjek melaporkan bahwa sakit fisik yang dialami selalu membuat kondisinya memburuk dengan intensitas nyeri yang meningkat sehingga waktu yang dibutuhkan istirahat di ruang perawatan UKS pada rentang 3-4 jam. Berbagai keluhan yang sering dialami secara berulang seperti keluhan pada ulu hati dan kesulitan bernafas serta sakit kepala sebelah.

Selama intervensi, relaksasi otot dengan penggunaan sugesti pada fase awal memasuki kondisi hipnosis diberikan secara berulang. Pemberian sugesti positif pada tahap deepening ditanamkan untuk mengurangi intensitas nyeri fisik yang dikeluhkan pada anggota tubuh seperti; kepala, organ pencernaan dan sesak nafas serta memperkuat sugesti positif untuk mengatasi distress psikologis yang dialami secara lebih mandiri. Pasca hipnosis, subjek diberikan sugesti penguatan untuk mampu mengatasi problem psikomatis yang dialaminya

Subjek mengalami fase hipnotik yang tercerminkan rentang waktu yang singkat saat setelah diberikan di induksi pada tahap awal setelah diberikan sugesti. Hal ini terus menunjukkan pola yang sama selama treatmen diberikan dalam kunjungan-kunjungan subjek di ruang UKS. Kondisi ini tercerminkan setelah melakukan pemberian relaksasi terbimbing dengan pendekatan hipnosis. Dari hasil data kualitatif dengan pendekatan hasil wawancara, dilaporkan bahwa subjek mengalami perubahan terhadap rasa sakit yang dialaminya, mampu menghadapi persoalan psikologis yang dihadapi secara mandiri dan terjadinya pengurangan rasa nyeri subjek dengan pengurangan akan kebutuhan obat asma dan obat gastrointestinal serta frekuensi kunjungan ke Ruang UKS menurun secara drastis pada minggu ke tiga dan ke empat dalam fase traupetik dengan menggunakan media hipnosis.

Hasil pemeriksaan menggunakan instrumen SCL90-R diperoleh angka $29 \%$ pada psikosomatis yang mengindikasikan bahwa adanya perbaikan keluhankeluhan psikosomatis yang dialami oleh subjek pada meinggu ke 4 setelah intervensi menggunakan hipnoterapi mengalami penurunan drastis dengan rentang perbedaan 58\% saat setelah di intervensi.

Tebel 1.

hasil pemeriksaan SCL-90 pra dan pasca intervensi

\begin{tabular}{cc} 
Hasil Pemeriksaan & Hasil Pemeriksaan \\
symptom psikosomatis & $\begin{array}{c}\text { symptom psikosomatis } \\
\text { menggunakan SCL-90- } \\
\text { menggunakan SCL-90- } \\
\text { R sebelum diberikan } \\
\text { intervensi }\end{array}$ \\
$\begin{array}{c}\text { R setelah diberikan } \\
\text { intervensi }\end{array}$ \\
\hline
\end{tabular}

\begin{tabular}{lrrrr}
\hline \multicolumn{2}{c}{87} & \multicolumn{2}{c}{29} \\
\hline $\begin{array}{l}\text { Terjadinya penurunan } \\
\text { psikosomatis sebanyak }\end{array}$ & 58 pada & symptom & klinis \\
diberikan perlakuan. & & setelah \\
\hline
\end{tabular}

Intensitas perawatan pada minggu ke tiga terjadi penurunan. Rentang waktu istirahat hanya 50-60 
menit. Selama perawatan dalam rentang waktu istirahat tersebut dipergunakan untuk proses traupetik menggunakan hipnosis dengan menanamkan sugesti positif terhadap perbaikan kondisi psikologis subjek. Frekuensi kunjungan berkurang secara signifikan. Minggu ke dua hanya 2 kali kunjungan dengan keluhan sakit kepala tanpa disertai keluhan pencernaan dan asma, dan minggu ke tiga adalah kunjungan untuk sesi traupetik tanpa laporan keluhan psikosomatis yang dialami subjek.

\section{Diskusi}

Dari hasil data kualitatif dengan pendekatan hasil wawancara, dilaporkan bahwa subjek mengalami perubahan terhadap rasa sakit yang dialaminya seperti gangguan gastrointestinal, sakit kepala, dan asma serta munculnya rasa percaya diri subjek dalam menghadapi persoalan psikologis yang dihadapi secara mandiri dan terjadinya pengurangan rasa nyeri subjek dengan pengurangan akan kebutuhan obat asma dan obat gastrointestinal serta frekuensi kunjungan ke Ruang UKS menurun secara signifikan. Dari data kuantitatif berdasarkan hasil laporan SCL-90-R ditemukan perbedaan yang signifikan dalam symptom klinis pada psikosomatis dengan rentang 58 poin pasca diberikannya hipnoterapi sebagai media traupetik terhadap psikosomatis yang dialami subjek.

Hal ini dapat dijelaskan oleh temuan penelitian bahwa fase hipnosis pada tahap awal pada subjek yang didiagnosis dengan gangguan psikosomatik mengalami tingkat penurunan stres psikologis dan juga terbentuknya keyakinan baru yang ditimbulkan oleh sugesti terhadap konsep sakit yang dialami subjekSugesti positif yang diberikan selama proses berlangsung dan pasca-hipnotis berkontribusi terhadap pengurangan rasa sakit pada pernafasan dan penceernaan serta kemampuan dalam mengelola simtomatologinya dengan cara yang aktif dan berdampak positif bagi kesehatan fisik subjek, juga kemampuan subjek dalam mengelola disstress psikologis yang dialaminya.

Hipnoterapi dapat mengurangi keluhan nyeri dan mengatasi kecemasan (Abdeshahi, et al., 2013). Selain itu, hipnoterapi juga mampu menyembuhkan psikosomatis (Holdevici \& Craciun, 2012., Gunawan, 2007., dan Hakim, 2010) menyembuhkan post traumatic syndrome disorder (Enea dan Dafiniou 2012), dyspepsia atau gangguan gastrointestinal (Calvert, et al, 2002), migrain (Emmerson \& Trexler, 1999). Dalam kondisi hipnosis, sugesti positif akan mampu mengubah kebiasan negatif (Putranto, 2016) pada subjek yang mendapatkan trapi hipnosis.

Penggunaan sugesti positif mampu mengubah pandangan negatif yang tertanam dalam pikiran subjek dan menjadi believe system serta mampu menjadi kebiasaan baru dalam berpikir dan bertindak secara adaptif. Penggunaan sugesti dalam hipnosis mampu mengatasi persoalan gangguan emosional (Alladin, 2008). Dan hipnosis merupakan langkah strategis dalam memperogram ulang pikiran bawah sadar (Banyan \& Kein, 2001). Program bawah sadar melalui penggunaan sugesti dalam proses hipnosis akan menghasilkan proses traupetik pada subjek yang mengalami distress psikologis maupun gangguan fisik yang dialaminya.

\section{Kesimpulan}

Hasil penelitian ini menunjukkan efektifitas hipnoterapi dalam mengobati keluhan pencernaan dan asma serta menurunkan tingkat rasa nyeri yang dialami oleh santriwati MA Muallimat dengan gangguan psikosomatis pasca diberikan hipnosis yang secara langsung berdampak terhadap intensitas nyeri fisik serta keluhan-keluhan fisik akibat distress psikologis yang dideritanya. Sugesti yang ditanamkan dialam bawah sadar mempengaruhi perubahan kondisi psikosomatis dengan gangguan gastrointestinal, sakit kepala dan asma yang dialami subjek akibat distress psikologis akibat adanya distorsi kognitif.

Hal ini mengidentifikasikan bahwa relaksasi pada fase hipnotik terhadap subjek sangat mempengaruhi kondisi fisik dan psikologis yang berdampak langsung terhadap pengurangan keluhan fisik dan keluhan-keluhan psikosomatis yang ditimbulkannya serta berkurangnya frekuensi perawatan di ruang UKS pasca mendapatkan hipnoterapi sebagai media utama dalam peroses penyembbuhan terhadap subjek yang menderita psikosomatis. Sugesti positif dapat memberikan relaksasi fisik yang dalam dan mampu merubah distrosi kognitif yang menjadi pemicu munculnya beragam keluhan fisik pada psikosomatis. 


\section{Saran}

Disarankan untuk penelitian selanjutnya menggunakan metode yang lebih ketat dengan melibatkan sampel penelitian berjumlah besar dengan variable penelitian yang beragam. Direkomendasikan kepada penderita psikosomatis untuk melakukan self healing dengan menggunakan self hypnosis untuk mengurangi keluhan fisik yang dialami akibat distorsi kognitif yang memicu munculnya keluhan psikosomatis.

\section{Referensi}

Abdeshahi, Seyyed Kazem., et al. (2015). Effect of hypnosis on induction of local anaesthesia, pain perception, control of haemorrhage and anxiety during extraction of third molars: A case - control study. journal of cranio - maxillo - facial surgey 41: 310315.

Alladin, Assen. (2008). Cognitive Hypnotherapy: An integrated approach to the treatment of emotional disorder. England: Jhon wiley \& Sons Ltd.

Ardani, Tristiadi Ardi. (2008). Psikiatri Islam. Malang: UINMalang Press.

Banyan, Calvin D., \& Kein, Gerald F., (2001). Hypnosis and Hypnotherapy: Basic to advanced techniques and procedures for the professional. St, Paul, Minnoseta : Abbot Publishing House, Inc.

Budi, Prabowo Prasetyo Budi dan Rizali, Ervin. (2010). Cara cepat menguasai hypnohealing. Jogjakarta: Leutika.

Calvert, E.L., et al. (2002). Longterm improvement in functional dyspepsia using hipnotherapy. Gastroenterology 123, 1778-1785.

Emmerson, G. H., \& Trexler, G. (1999). An Hipnotic intervention for migraine control. Australian journal of clinical \& experimental hypnosis $27,54-61$.

Enea, Violeta., \& Dafinoiu. (2012). Cognitive Hypnotherapy in addressing the posttraumatic stress disorder. Procedia - Social and Behavioral Sciences 36, 36 40.

Gunawan, Adi W. (2007). Hipnosis (The Art of Subconscious Comunication). Jakarta: Gramedia Pustaka Utama.

Gunawan. Adi W. (2007). Hypnotherapy (the Art of Subconscious Restructuring). Jakarta: Gramedia Pustaka Utama.

Guze, Barry., Siegel, J. Daniel., Richeimer, Steven dan. (1997). Buku saku psikiatri. Alih bahasa oleh R.F. Maulany. Jakarta: EGC.

Hakim, Andri. (2010). Hipnoterapi (Cara tepat dan cepat mengatasi stres, fobia, trauma, dan gangguan mental lainnya). Jakarta: Visi Media.

Halgin, Richard, P., \& Whitbourne, Susan Krauss. (2010). Psikologi Abnormal: Perspektif klinis pada gangguan psikologis, edisi 6. Penerjemah: Aliya Tusya'ni., dkk. Jakarta: Salemba Humanika.
Holdevici, Irina., \& Craciun, Barbara. (2012). The Use of Ericksonian Hypnosis in Somatic Disorder. Procedia - Social and Behavioral sciences 33, 75 - 79.

Hunter, Roy. (2011). Seni Hipnosis. Alih Bahasa oleh Paramita. Jakarta: PT Indeks.

Hukom, A.J. (1979). Hypnotherapy atau Hipnosis Kedokteran (Pedoman Menggunakan Hipnosis dalam Ilmu Kedokteran). Jakarta: Yayasan Dharma Graha.

Junaidi, Iskandar. (2012). Anomali Jiwa. Yogyakarta: CV. Andi Offset

Prabowo. 2009. Hipnomedik, hipnoterapi \& hypnopregnancy. Jogjakarta: Nuha Medika.

Putranto, Kasandra. (2016). Aplikasi cognitive behavior dan behavior activation dalam intervensi klinis. Jakarta: Grafindo books media.

Schmitz, Norberto., et al. (2002). Properties of the symptom check list (SCL-90-R) In A Psychosomatic Consultation - Liaison Setting. psychological Reports 90, 1201-1207.

Shaughnessy, Jhon. J., Dkk. Metode Penelitian dalam psikologi (edisi ke sembilan). Alih Bahasa oleh Ellys Tjo. Jakarta: Salemba Humanika.

Williams, Lippincott., \& Wilkins . (2004). Buku Saku Psikiatri. Alih bahasa; Martina Wiwie S. Nasrun. Cetakan I. Jakarta: Penerbit Buku Kedokteran EGC.

Wong, Willy dan Hakim, Andri. (2009). Dahsyatnya Hipnosis. Jakarta: Visi Media. 